\title{
Effect of low dose of intrathecal pethidine on the incidence and intensity of shivering during cesarean section under spinal anesthesia: a randomized, placebo-controlled, double-blind clinical trial
}

\author{
This article was published in the following Dove Press journal: \\ Drug Design, Development and Therapy \\ 20 September 2016 \\ Number of times this article has been viewed
}

\author{
Shoaleh Shami' \\ Karim Nasseri ${ }^{2}$ \\ Mousa Shirmohammadi ${ }^{3}$ \\ Farzad Sarshivi ${ }^{3}$ \\ Negin Ghadami ${ }^{3}$ \\ Ebrahim Ghaderi ${ }^{4}$ \\ Mokhtar Pouladi ${ }^{5}$ \\ Arvin Barzanji' \\ 'Department of Surgical Nursing, \\ School of Nursing and Midwifery, \\ Kurdistan University of Medical \\ Sciences, Sanandaj, Iran; ${ }^{2}$ Department \\ of Anesthesia and Intensive Care, \\ Social Determinants of Health \\ Research Center, Faculty of Medicine, \\ Kurdistan University of Medical \\ Sciences, Sanandaj, Iran; ${ }^{3}$ Department \\ of Anesthesia and Intensive Care, \\ Faculty of Medicine, Kurdistan \\ University of Medical Sciences, \\ Sanandaj, Iran; ${ }^{4}$ Social Determinants \\ of Health Research Center, Kurdistan \\ University of Medical Sciences, \\ Sanandaj, Iran; ${ }^{5}$ Student Research \\ Committee, Faculty of Medicine, \\ Kurdistan University of Medical \\ Sciences, Sanandaj, Iran
}

Correspondence: Karim Nasseri Department of Anesthesia and Intensive Care, Social Determinants of Health Research Center, Faculty of Medicine, Kurdistan University of Medical

Sciences, Pasdaran Street, 66177/3446,

Sanandaj, Iran

Tel +988733660733

Fax+98 87I 33233600

Email Nasseri_k@muk.ac.ir
Introduction: Shivering is among the unpleasant and potentially harmful side effects of spinal anesthesia. The aim of this randomized double-blind clinical trial was to compare the antishivering effect of two different doses of intrathecal pethidine on the incidence and intensity of shivering and other side effects in patients who underwent cesarean section.

Methods: In this study, 150 parturient females scheduled for nonemergent cesarean section were randomly allocated to three groups. Spinal anesthesia was performed with $0.5 \%$ hyperbaric bupivacaine (12.5 mg), plus $0.5 \mathrm{~mL}$ of $0.9 \%$ saline in the standard group ( $\mathrm{S}$ group), and the same dose of bupivacaine with $5 \mathrm{mg}$ (P5 group) or $10 \mathrm{mg}$ of pethidine (P10 group). Demographic and surgical data, incidence and intensity of shivering (primary outcome), hemodynamic indices, forehead and core temperatures, maximum sensory level, Apgar scores, and adverse events were evaluated by a blinded observer.

Results: There were no significant differences between the three study groups regarding the demographic and surgical data, hemodynamic indices, core temperatures, and maximum sensory level $(P>0.05)$. The incidence and intensity of shivering were significantly less in the P5 and $\mathrm{P} 10$ groups $(P<0.001)$ when compared with the $\mathrm{S}$ group. There were no significant differences between groups for secondary outcomes, except pruritus, which was more common in the $\mathrm{P} 5$ and $\mathrm{P} 10$ groups when compared with the $\mathrm{S}$ group $(P=0.01)$.

Conclusion: Low dose of intrathecal pethidine is safe, and can decrease the incidence and intensity of shivering during cesarean section, without having major side effects.

Keywords: shivering, cesarean section, intrathecal pethidine, prevention, nausea, vomiting

\section{Introduction}

Spinal anesthesia (SA), due to the advantages such as rapid start, high success rate, and minimal impact of drugs on both mother and fetus, is the more common preferred method of anesthesia for cesarean section (CS), and has become increasingly popular among the physicians and patients. ${ }^{1}$ Shivering with more than $55 \%$ incidence is among the common and pretty unpleasant complications of SA. ${ }^{2}$ Shivering increases oxygen consumption two to three times, production of carbon dioxide, lactic acidosis, cardiac output, tachycardia, and intraocular pressure, and interferes with monitoring of oxygen saturation, electrocardiogram (ECG), and blood pressure. ${ }^{2-5}$ These side effects are problematic, particularly in pregnant females. So, preventing shivering during SA is important especially in pregnant patients and those with limited cardiopulmonary capacity. ${ }^{5}$ Although, the exact mechanism of shivering following SA is unknown; 
theories such as heat loss during surgery, increased sympathetic tone, pain, and released systemic pyrogens have been proposed. ${ }^{2,4}$

For a long period of time, intravenous (IV) pethidine has been used for the treatment and prevention of shivering during surgery and emergence. ${ }^{4-6}$ Pethidine in equivalent dose is more effective when compared with other $\mu$-opioid receptor agonists such as fentanyl, alfentanil, sufentanil, and morphine. ${ }^{6,7}$ It seems that IV pethidine exerts its antishivering effects via the activation of kappa-opioid receptors. ${ }^{8-10}$

Unlike IV pethidine, there is controversy about the effect of intrathecal pethidine and its advantages and disadvantages. Roy et $\mathrm{al}^{11}$ have tried intrathecal pethidine $(0.2 \mathrm{mg} / \mathrm{kg})$ in pregnant females, and concluded that it reduces the incidence of shivering without significant adverse effects. Khan et $\mathrm{al}^{12}$ believe that although intrathecal pethidine reduces shivering during CS under SA, it increases the incidence of nausea and vomiting; therefore, the drug should not be used. Due to these inconsistencies and the lack of information in other studies about the optimal dose of intrathecal pethidine for the prevention of shivering without causing side effects, the present study was designed to evaluate and compare the effect of adding two different low doses of pethidine (5 or $10 \mathrm{mg}$ ) to spinal bupivacaine on the incidence and intensity of shivering, and related side effects in patients who underwent CS under SA.

\section{Methods Design}

This was a parallel randomized double-blind controlled trial approved by the Institutional Clinical Research Ethics Committee (Kurdistan University of Medical Sciences), the study was registered at the Iranian Registry of Clinical Trials (www.irct.ir, IRCT2015090223869N1), and all subjects provided written informed consent to participate in study. The protocol is available with the research deputy at Kurdistan University of Medical Sciences. One hundred and fifty parturient females with inclusion criteria of age range: 18-45 years, and with American Society of Anesthesiologists physical status I or II who were indicated for nonemergent CS under SA at the Besat Hospital (Sanandaj, Iran) were enrolled in this study by one of the anesthesiology colleges. The exclusion criteria included: rejection of SA by the patient, history of spinal surgery, having any contraindications for SA, preeclampsia, hypertension, diabetes, valvular heart disease, ischemic heart disease, pulmonary hypertension, history of drug abuse, excessive bleeding during surgery requiring transfusion, need for analgesic or sedative drugs due to inadequacy of blocks during the procedure, and history of sensitivity to pethidine.

Randomization numbers were generated using random allocation software (version 1; Isfahan University of Medical Sciences, Isfahan, Iran) by a methodologist.

\section{Preanesthetic interventions}

After entering the operating room, two IV cannula $(\mathrm{G}=18)$ were fixed on the dorsum of the patients' hands, and the patients underwent ECG, noninvasive blood pressure, pulse rate, and pulse oximetry monitoring. Before performing SA, all the patients were infused with $500 \mathrm{~mL}$ of Ringer lactate, which had been heated to $37^{\circ} \mathrm{C}$. For all participants, SA was conducted by an expert anesthesiologist who was unaware of the patients' grouping and was not involved in data collection.

\section{Study interventions}

SA was carried out using $12.5 \mathrm{mg}$ of $0.5 \%$ hyperbaric bupivacaine (Marcaine ${ }^{\circledR}$, AstraZeneca, Cambridge, UK) and $0.5 \mathrm{~mL}$ of normal saline in the standard group ( $\mathrm{S}$ group), while $5 \mathrm{mg}$ of the pethidine (Demerol, Sintetica, Mendrisio, Switzerland) was added to the same dose of spinal bupivacaine in the P5 group, and $10 \mathrm{mg}$ of the preservative-free pethidine was added to the same dose of spinal bupivacaine in the P10 group. In all patients, SA was performed in the sitting position, using a Quincke spinal needle $(\mathrm{G}=25)$ and in L3-L4 or L4-L5 space, using the midline approach. Study medications were prepared by an anesthetic nurse who was unaware of the patients' grouping, in similar syringes and same volumes (the volume was $\sim 3 \mathrm{~mL}$ after adding the required amount of normal saline for all the three groups). Upon completion of SA, the position of patients was changed immediately to supine while the pelvis was tilted, and all the patients received oxygen $(6 \mathrm{~L} / \mathrm{min})$ through a face mask.

\section{Tools and measurements}

The time of completion of intrathecal injection was considered as T0. Highest sensory block level was assessed every 2 minutes for the first 10 minutes, and then every 5 minutes for the next 30 minutes, using the pin prick method. Standard monitoring for all patients was maintained, and heart rate and blood pressure values were recorded at baseline and every 15 minutes during surgery and recovery (baseline, 15, 30, 45,60 , and 75 minutes). Patients were covered with a layer of drapes and a blanket during the operation and recovery periods, respectively.

Using temperature control system, the temperature of the operation and recovery room was maintained at $24^{\circ} \mathrm{C}-26^{\circ} \mathrm{C}$. The patient's core body and forehead temperature was 
measured throughout the operation and recovery periods, using Braun tympanic (ThermoScan Tympanic Ear Pro 4000 Thermometer; Hoofddorp, the Netherlands) and forehead (Braun Forehead thermometer NTF3000; Kronberg, Germany) thermometer, every 15 minutes from the onset of spinal block until discharge from the recovery room. The neonate Apgar score at 1 and 5 minutes, beginning time of shivering in case of occurrence, and incidence and intensity of shivering (primary outcome) were recorded. The method of Crossley and Mahajan ${ }^{13}$ was used for measuring the intensity of shivering. The scoring was as follows: $0=$ without shivering; $1=$ piloerection or peripheral vasoconstriction without visible shivering; $2=$ muscular activation only in one group of muscles; $3=$ muscular activation in more than one group of muscles without generalized shivering; $4=$ generalized shivering. The time from T0 to the end of surgery was defined as "duration of surgery", and it was recorded.

In the case of grade 2 or higher grades of shivering, $30 \mathrm{mg}$ of pethidine was administered intravenously to patients. Any spinal block side effects that were detected (including pruritus, hypotension, bradycardia, nausea, and vomiting) were recorded. Hypotension was defined as a decrease of $>20 \%$ from baseline in systolic blood pressure. Bradycardia was defined as a decrease of heart rate $<50$ beat/min. Hypotension and bradycardia were treated with IV ephedrine (5-10 mg) and atropine $(0.5 \mathrm{mg})$, respectively. Nausea and vomiting were graded as: mild (one crisis of nausea or vomiting), moderate (more than one crisis of nausea or vomiting, but not persistent), and severe (persistent nausea and vomiting), and IV ondansetron (1 mg) was administered as an escape drug for severe cases.

\section{Sample size calculation}

To determine a $40 \%$ difference in the incidence of shivering between the groups (shivering incidence in control and intervention groups equal to $55 \%$ and $15 \%$ ) and $90 \%$ power and $5 \%$ type I error, a sample size of 45 cases was calculated in each group. Fifty participants were evaluated in each group.

\section{Data analysis}

Data were analyzed using SPSS 16 (SPSS Inc, Chicago, IL, USA). Normality of distribution was assessed by Kolmogorov-Smirnov test, and ordinal variables were considered as nonnormal distribution. Age, pre/postoperative value of hemoglobin and hematocrit, and duration of surgery were compared using analysis of variance test. Shivering intensity and sensory block levels were compared using the Kruskal-Wallis among three groups. The Mann-Whitney $U$-test was used and $P$-value corrected by Bonferroni correction for multiple comparison. Incidence of shivering and complications were compared using the chi-square test among the three groups. Also repeated measurement test was used to compare the trend of systolic and diastolic blood pressure, core temperature, and pulse rate among three groups during the study. $P<0.05$ was considered as statistically significant.

\section{Results}

From 184 participants, 150 participants met inclusion criteria and they were randomized by an anesthetic nurse who was not involved in the outcome evaluation. The flow diagram of randomized patients is shown in Figure 1. There was no significant difference according to the age, duration of surgery, preoperative hemoglobin, and hematocrit levels between the three groups (Table 1).

\section{Systolic blood pressure}

There were no significant differences in the trend of systolic blood pressure between the P5 $(P=0.2)$ and P10 $(P=0.25)$ groups when compared with the $\mathrm{S}$ group. Likewise, no significant difference was observed between the P5 and P10 groups $(P=0.53)$ (Figure 2$)$.

\section{Diastolic blood pressure}

There were no significant differences in the trend of diastolic blood pressure between the P5 $(P=0.71)$ and P10 $(P=0.78)$ groups when compared with the $\mathrm{S}$ group. Similarly, no significant difference was observed between the P5 and P10 groups $(P=0.72)$ (Figure 3$)$.

\section{Pulse rate}

There were no significant differences in the trend of pulse rate between $5 \mathrm{mg}(P=0.89)$ and $10 \mathrm{mg}(P=0.92)$ intrathecal pethidine groups compared with the placebo group. Also no significant difference was observed between the 5 and $10 \mathrm{mg}$ intrathecal pethidine group $(P=0.75)$ (Figure 4$)$.

\section{Core temperature}

There were no significant differences in the trend of forehead temperature between $5 \mathrm{mg}(P=0.26)$ and $10 \mathrm{mg}(P=0.43)$ intrathecal pethidine groups compared with the placebo group. Also no significant difference was observed between the 5 and $10 \mathrm{mg}$ intrathecal pethidine group $(P=0.83)$ (Figure 5).

\section{Shivering}

Incidence of shivering was significantly higher in the $\mathrm{S}$ group $(25,50 \%)$ when compared with the P5 and P10 groups 


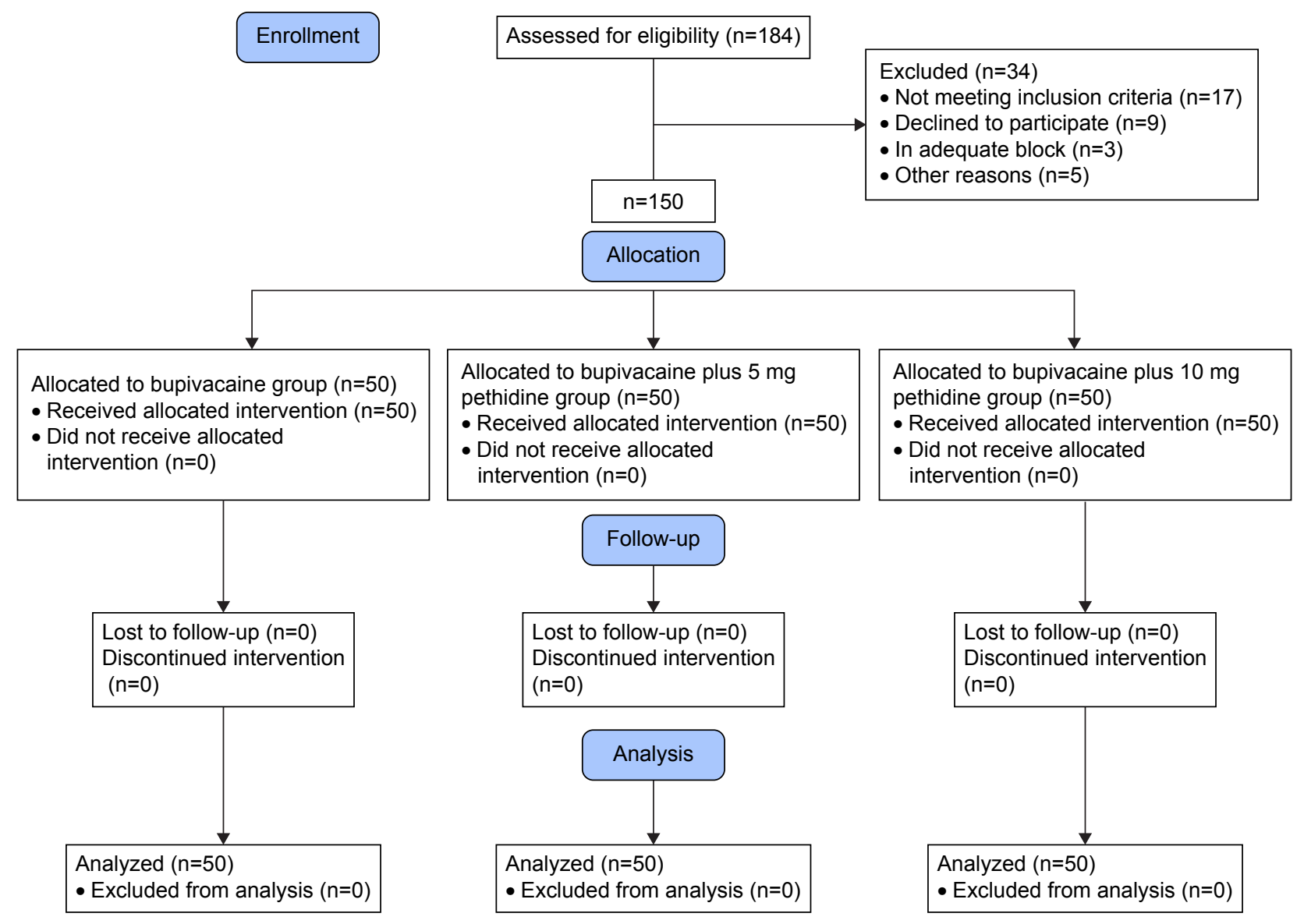

Figure I Group randomization according to CONSORT 2010.

Abbreviation: CONSORT, Consolidated Standards of Reporting Trials.

(13, 26\%; and 3, 6\%, respectively) $(P<0.001)$. Also shivering intensity was significantly different between the groups using Kruskal-Wallis test $(P<0.001)$. Mann-Whitney test showed significant difference between the $\mathrm{S}$ group, and the P5 $(P=0.009)$ and P10 groups $(P<0.001)$. Likewise, there was significant difference between the P5 and P10 groups with respect to shivering intensity $(P=0.02)$ (Table 2$)$.

\section{Adverse effect of the intervention}

The incidence of nausea $(P=0.25)$, vomiting $(P=0.14)$, hypotension $(P=0.66)$, and bradycardia $(P=0.17)$ was not different between the groups. The incidence of pruritus was significantly higher in the P10 group when compared with the P5 group $(P=0.01)$. However, no pruritus was noted in patients of the $\mathrm{S}$ group.

Chi-square test showed that prescriptions of ephedrine and atropine in the three groups were comparable but prescriptions of ondansetron $(P=0.03)$ and additional pethidine $(P=0.004)$ were significantly different between the three groups $(P=0.03)$. There were eight $(16 \%)$ patients from the $\mathrm{S}$ group and two (4\%) from the P5 group who required additional i.v. pethidine as an escape drug for shivering treatment $(P=0.004)$. However, none of the patients in the P10 group received additional IV pethidine (Table 3 ).

Table I Comparison of demographic variables and paraclinical data of the participants in three groups before the intervention

\begin{tabular}{|c|c|c|c|c|}
\hline Variable & $\begin{array}{l}\text { Placebo } \\
\text { group, } N=50\end{array}$ & $\begin{array}{l}\text { Pethidine } 5 \text { mg } \\
\text { group, } N=50\end{array}$ & $\begin{array}{l}\text { Pethidine } 10 \mathrm{mg} \\
\text { group, } \mathrm{N}=\mathbf{5 0}\end{array}$ & P-value \\
\hline Age; mean \pm SD & $31.8 \pm 4.7$ & $3 I \pm 5.5$ & $31.5 \pm 5.6$ & 0.76 \\
\hline Duration of surgery; mean \pm SD & $55.2 \pm 15.1$ & $57.6 \pm 15.9$ & $53.8 \pm 13.7$ & 0.44 \\
\hline Preoperative hemoglobin level; mean \pm SD & $12.5 \pm 1.2$ & $12.5 \pm 1.1$ & $12.5 \pm 1.2$ & 0.85 \\
\hline Preoperative hematocrit level; mean \pm SD & $38.1 \pm 3.7$ & $37.7 \pm 3$ & $37.8 \pm 3.3$ & 0.71 \\
\hline
\end{tabular}

Note: Analysis of variance test was used to compare the variables among the three groups.

Abbreviation: SD, standard deviation. 


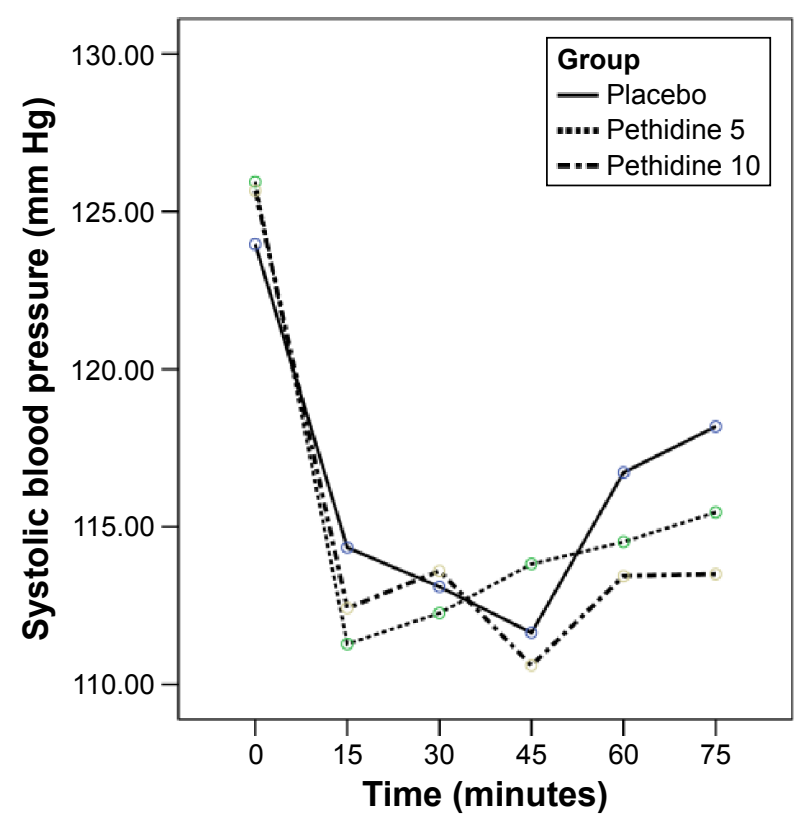

Figure 2 Comparison of the trend of systolic blood pressure during the study among control and intervention groups.

Notes: Analysis was done by repeated measurement. $5 \mathrm{mg}$ pethidine vs placebo: $P=0.2,10 \mathrm{mg}$ pethidine vs placebo: $P=0.2,5 \mathrm{mg}$ pethidine vs $10 \mathrm{mg}$ pethidine: $P=0.5$.

\section{Discussion}

In this study, it was observed that adding pethidine to intrathecal bupivacaine was significantly effective in providing prophylaxis against shivering in CS under SA. The incidence of shivering as the main outcome was $50 \%$ in the control group, $26 \%$ in the P5 group, and 6\% in the P10 group. Similarly,

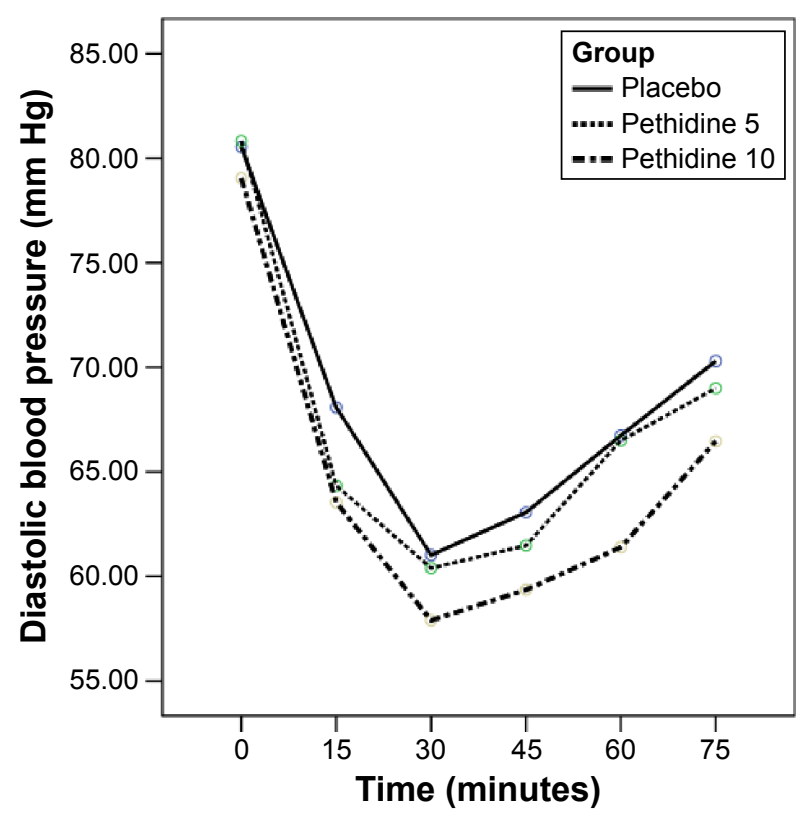

Figure 3 Comparison of the trend of diastolic blood pressure during the study among control and intervention groups.

Notes: Analysis was done by repeated measurement. $5 \mathrm{mg}$ pethidine vs placebo: $P=0.7,10 \mathrm{mg}$ pethidine vs placebo: $P=0.7,5 \mathrm{mg}$ pethidine vs $10 \mathrm{mg}$ pethidine: $P=0.7$.

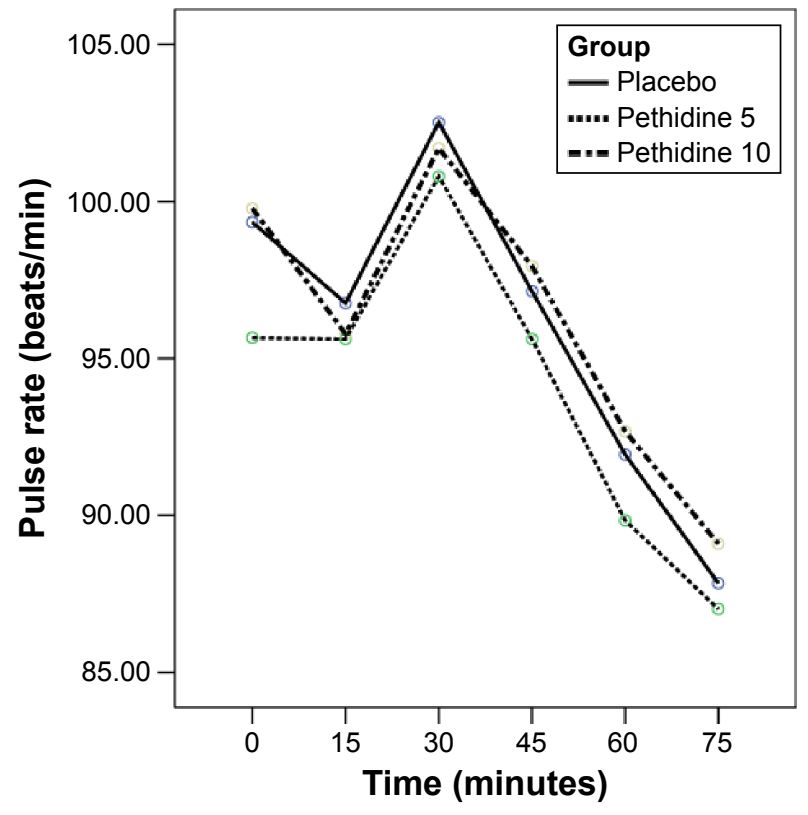

Figure 4 Comparison of the trend of pulse rate during the study among control and intervention groups.

Notes: Analysis was done by repeated measurement. $5 \mathrm{mg}$ pethidine vs placebo: $P=0.8,10 \mathrm{mg}$ pethidine vs placebo: $P=0.9,5 \mathrm{mg}$ pethidine vs $10 \mathrm{mg}$ pethidine: $P=0.7$.

there was a significant difference in the intensity of shivering between the three groups in this study. The incidence of perioperative complications, including nausea, vomiting, hypotension, and bradycardia, was not different between the groups, while pruritus was significantly higher in the P10 group when compared with the $\mathrm{P} 5$ group, and absent in the S group.

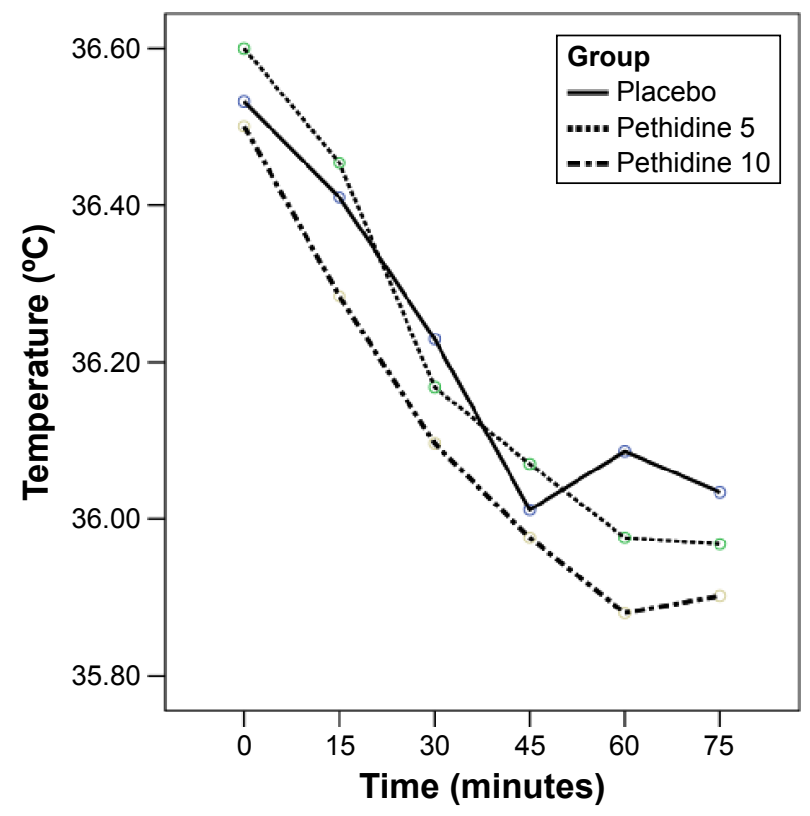

Figure 5 Comparison of the trend of core body temperature during the study among control and intervention groups.

Notes: Analysis was done by repeated measurement. $5 \mathrm{mg}$ pethidine vs placebo: $P=0.2,10 \mathrm{mg}$ pethidine vs placebo: $P=0.4,5 \mathrm{mg}$ pethidine vs $10 \mathrm{mg}$ pethidine: $P=0.8$. 
Table 2 Comparison of outcomes in the three groups after the intervention

\begin{tabular}{|c|c|c|c|c|c|}
\hline Variable & $\begin{array}{l}\text { Placebo } \\
\text { group, } \mathrm{N}=\mathbf{5 0}\end{array}$ & $\begin{array}{l}\text { Pethidine } 5 \mathrm{mg} \\
\text { group, } \mathrm{N}=50\end{array}$ & $\begin{array}{l}\text { Pethidine } 10 \mathrm{mg} \\
\text { group, } \mathrm{N}=\mathbf{5 0}\end{array}$ & $\begin{array}{l}\text { Total, } \\
\mathrm{N}=150\end{array}$ & $\begin{array}{l}P \text {-value } \\
(95 \% \mathrm{Cl})\end{array}$ \\
\hline Intensity of shivering; n (\%) & & & & & $<0.00 I^{*}$ \\
\hline 0 (no shivering) & $25(50)$ & $39(78)$ & $48(96)$ & $112(74.7)$ & $(67.7-81.6)$ \\
\hline 1 & $17(34)$ & $9(18)$ & $2(4)$ & $28(18.7)$ & $(12.5-24.9)$ \\
\hline 2 & $7(14)$ & $2(4)$ & 0 & $9(6)$ & $(2.2-9.8)$ \\
\hline 3 & $I(2)$ & 0 & 0 & $\mathrm{I}(0.7)$ & $(0-2)$ \\
\hline 4 (highest) & 0 & 0 & 0 & 0 & - \\
\hline \multicolumn{6}{|l|}{ Intensity of shivering } \\
\hline Median (25th-75th quartile) & $0.5(0-1)$ & $0(0-0)$ & $0(0-0)$ & $0(0-1)$ & $0.009^{\mathrm{a}, \mathrm{f}}$ \\
\hline \multirow[t]{2}{*}{ Mean $( \pm S D)$} & $0.68(0.79)$ & $0.26(0.53)$ & $0.04(0.2)$ & $32(0.62)$ & $<0.00 \mathrm{I}^{\mathrm{b}}$ \\
\hline & & & & & $0.02^{c}$ \\
\hline
\end{tabular}

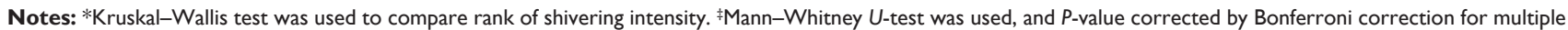

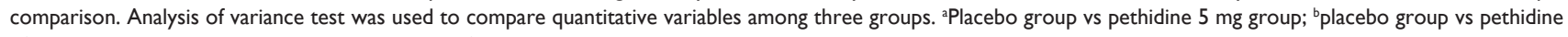
$10 \mathrm{mg}$ group; 'pethidine $5 \mathrm{mg}$ group vs pethidine $10 \mathrm{mg}$ group.

Abbreviations: $\mathrm{Cl}$, confidence interval; SD, standard deviation.

Hong and Lee ${ }^{14}$ compared adding $10 \mathrm{mg}$ of pethidine to $8-10 \mathrm{mg}$ of $0.5 \%$ intrathecal hyperbaric bupivacaine with bupivacaine alone during elective CS under combinedspinal epidural anesthesia. They indicated that incidences of shivering decreased from $23.3 \%$ in plain bupivacaine to $3.3 \%$ in $10 \mathrm{mg}$ of intrathecal pethidine. They also showed that adding pethidine to intrathecal bupivacaine lowered the intensity of shivering. Complications of SA including nausea, vomiting, and pruritus were similar in the groups used in the studies of Hong and Lee. ${ }^{14}$ In the study of Anaraki and Mirzaei, ${ }^{1}$ the efficacy of three different doses of pethidine $(0.2,0.3$, and $0.4 \mathrm{mg} / \mathrm{kg})$ as adjuvant was compared with $10 \mathrm{mg}$ of $0.5 \%$ heavy spinal bupivacaine alone in females scheduled for elective CS. They concluded that, as the dose of pethidine increased, the incidence and intensity of shivering decreased, while the incidence of nausea, vomiting, and pruritus increased. Khan et $\mathrm{al}^{12}$ also showed that the addition of 12.5 or $25 \mathrm{mg}$ of pethidine to $10 \mathrm{mg}$ of $0.5 \%$ intrathecal bupivacaine lowered the incidence of shivering following SA during CS. In the study of Khan et al, ${ }^{12}$ the intensity of shivering was comparable in those two experimental groups that received intrathecal pethidine (12.5 or $25 \mathrm{mg}$ ), whereas nausea and vomiting occurred more frequently with higher doses of pethidine. With regards to the incidence and intensity of shivering, the results of these three studies are in concordance with this study's results.

In this study, no difference was observed in the tympanic and forehead temperature between groups. Environment temperature was the same in the operation and recovery room during the study period and was kept at $24^{\circ} \mathrm{C}-26^{\circ} \mathrm{C}$. So, these factors could not affect the results of this study.

Based on the above-mentioned studies, ${ }^{1,12,14}$ different doses of intrathecal pethidine are effective in controlling perioperative shivering, while higher doses eventuate to more nausea, vomiting, and pruritus.

Possible suggested etiologies of shivering following SA include internal redistribution of core temperature, unrestricted spinal reflexes, loss of thermoregulatory vasoconstriction below the level of the blockade, and reduction of vasoconstriction threshold. ${ }^{4,15}$ In this study, both tympanic core body and forehead temperature were decreased to about $0.6^{\circ} \mathrm{C}$ in all the three groups, and there were no significant differences among the groups in this regard. So, in the present study, the effects of pethidine on redistribution of core

Table 3 Adverse effects and drug used as rescue treatment in three study groups

\begin{tabular}{|c|c|c|c|c|c|}
\hline Variable & $\begin{array}{l}\text { Placebo } \\
\text { group, } \mathbf{N}=\mathbf{5 0}\end{array}$ & $\begin{array}{l}\text { Pethidine } 5 \text { mg } \\
\text { group, } N=\mathbf{5 0}\end{array}$ & $\begin{array}{l}\text { Pethidine } 10 \mathrm{mg} \\
\text { group, } \mathrm{N}=\mathbf{5 0}\end{array}$ & $\begin{array}{l}\text { Total, } \\
\mathrm{N}=150\end{array}$ & $\begin{array}{l}P \text {-value } \\
(95 \% \mathrm{Cl})\end{array}$ \\
\hline Hypotension; n (\%) & $34(68)$ & $33(66)$ & $37(74)$ & $104(69.3)$ & $0.66(61.9-76.7$ \\
\hline Bradycardia; n (\%) & $3(6)$ & $0(0)$ & $\mathrm{I}(2)$ & $4(2.7)$ & $0.17(0.1-5.3)$ \\
\hline Nausea; n (\%) & $19(38)$ & $25(50)$ & $27(54)$ & 71 (47.3) & $0.25(39.3-55.3$ \\
\hline Vomiting; n (\%) & $6(12)$ & $13(26)$ & $13(26)$ & $32(21.3)$ & $0.14(14.7-27.8$ \\
\hline Pruritus; n (\%) & $0(0)$ & $3(6)$ & $13(26)$ & $16(10.7)$ & $0.01(5.7-15.6)$ \\
\hline Prescripted ephedrine; n (\%) & $34(68)$ & $33(66)$ & $37(74)$ & $104(69.3)$ & $0.09(61.9-76.7$ \\
\hline Prescripted atropine; n (\%) & $3(6)$ & $0(0)$ & $I(2)$ & $4(2.7)$ & $0.17(0.1-5)$ \\
\hline Prescripted ondansetron; n (\%) & $8(16)$ & $18(36)$ & $19(38)$ & $45(30)$ & $0.03(22.7-37.3$ \\
\hline Prescripted pethidine; $\mathrm{n}(\%)$ & $8(16)$ & $2(4)$ & $0(0)$ & $10(6.7)$ & $0.004(3-10)$ \\
\hline
\end{tabular}

Abbreviation: $\mathrm{Cl}$, confidence interval. 
temperature could not be the suggested cause of its effect on shivering incidence.

Although the antishivering mechanism of pethidine is not completely known, IV pethidine is supposed to be the gold standard to prevent and treat shivering. ${ }^{16}$ Rosow et al ${ }^{17}$ suggested that, in thermoneutral or warm environments, low doses of narcotics produce hyperthermia in some species. In the present study, the environment temperature was appropriate $\left(24^{\circ} \mathrm{C}-26^{\circ} \mathrm{C}\right)$, and tympanic core body and forehead temperature were decreased slightly $\left(0.6^{\circ} \mathrm{C}\right)$ in patients. Keeping ambient temperature in a convenient condition may play a role and decrease the intensity of shivering; this finding may help to give a clearer explanation of the low incidence of high-grade shivering in this study.

Pethidine is an agonist for $\mu$ - and $\kappa$-opioid receptors; however, it seems that the higher antishivering action of pethidine is via its affinity for the $\kappa$-receptor ${ }^{18,19}$ and takes place in plasma concentration of 0.6 and $1.8 \mu \mathrm{g} / \mathrm{mL} .{ }^{20} \mathrm{In}$ this study, 5 or $10 \mathrm{mg}$ of intrathecal pethidine was used, so it is unlikely that antishivering effects occurred via systemic absorption of pethidine.

There are concerns about the complications of intrathecal pethidine such as nausea and vomiting; as such, some of the studies discommend the use of intrathecal pethidine for CS during SA. ${ }^{1,12}$ Adding 5 or $10 \mathrm{mg}$ of pethidine did not increase the incidence of nausea and vomiting, as well as other complications such as hypotension, bradycardia, and respiratory depression in this study. These results are against those of Khan et al, ${ }^{12}$ and Anaraki and Mirzaei, ${ }^{1}$ but in agreement with the majority of studies that believed that low dose of intrathecal pethidine is effective as a prophylactic drug against shivering without increasing side effects. ${ }^{10,11,21}$

Results of the present study also showed that the need for the rescue dose of pethidine in the patients of the $\mathrm{S}$ group was higher than that of the P5 group. None of the patients of the P10 group required additional dose of pethidine for shivering treatment. These results are in agreement with the results of most studies. ${ }^{1,10,18}$ Although nausea and vomiting are among the complications of i.v. opioids, higher requirement to pethidine in the $\mathrm{S}$ group could contribute in increasing nausea and vomiting in this group. So, the same occurrence of nausea and vomiting in the three groups may be somewhat related to additional IV pethidine.

\section{Conclusion}

According to the results of this study, it can be concluded that adding low dose of pethidine ( 5 or $10 \mathrm{mg}$ ) to $12.5 \mathrm{mg}$ spinal bupivacaine is effective in reducing the incidence and intensity of shivering in parturient females who underwent
CS. It seems that disapproval of the low dose of intrathecal pethidine ( 5 or $10 \mathrm{mg}$ ) for the prevention of shivering during SA for CS due to fear of side effects such as nausea and vomiting is not authentic.

\section{Limitations}

One of the limitations of this study was that, although we designed to measure hemodynamic parameter and study primary outcome (shivering) at 15-minute intervals, these complications may occur between measurements, which may influence the analysis and trend of changes. Additionally, in the current study, fixed doses of pethidine were administered regardless of the body weight and body mass index of patients as a parameter within the demographic data.

\section{Acknowledgments}

This article is extracted from the practicum thesis of Dr Pouladi for general medicine degree reception, which was approved by the Medicine College Research Council of Kurdistan University of Medical Sciences. The authors thank the Research Council of Kurdistan University of Medical Sciences for partial support of this work.

\section{Disclosure}

The authors report no conflicts of interest in this work.

\section{References}

1. Anaraki AN, Mirzaei K. The effect of different intrathecal doses of meperidine on shivering during delivery under spinal anesthesia. Int $J$ Prev Med. 2012;3(10):706-712.

2. Crowley LJ, Buggy DJ. Shivering and neuraxial anaesthesia. Reg Anesth Pain Med. 2008;33(3):241-252.

3. Tsai YC, Chu KS. A comparison of tramadol, amitriptyline, and meperidine for postepidural anesthetic shivering in parturients. Anesth Analg. 2001;93(5):1288-1292.

4. De Witte J, Sessler DI. Perioperative shivering: physiology and pharmacology. Anesthesiology. 2002;96(2):467-484.

5. Han JW, Kang HS, Choi SK, Park SJ, Park HJ, Lim TH. Comparison of the effects of intrathecal fentanyl and meperidine on shivering after cesarean delivery under spinal anaesthesia. Korean J Anesthesiol. 2007; 52(6):657-662.

6. Alfonsi P, Sessler DI, Du Manoir B, Levron JC, Le Moing JP, Chauvin M. The effects of meperidine and sufentanil on the shivering threshold in postoperative patients. Anesthesiology. 1998;89:43-48.

7. Mauermann WJ, Shilling AM, Zuo Z. A comparison of neuraxial block versus general anesthesia for elective total hip replacement: a metaanalysis. Anesth Analg. 2006;103(4):1018-1025.

8. Patel D, Janardhan Y, Merai B, Robalino J, Shevde K. Comparison of intrathecal meperidine and lidocaine in endoscopic urological procedures. Can J Anaesth. 1990;37(5):567-570.

9. Chun DH, Kil HK, Kim HJ, Park C, Chung KH. Intrathecal meperidine reduces intraoperative shivering during transurethral prostatectomy in elderly patients. Korean J Anesthesiol. 2010;59(6):389-393.

10. Honarmand A, Safavi M, Dadkhah S, Amoushahi M. The effects of different doses of intrathecal meperidine on the incidence and severity of shivering during lower extremity orthopedic surgery under spinal anesthesia: a randomized, placebo-controlled, double blind-clinical trial. Adv Biomed Res. 2015;4:3. 
11. Roy J-D, Girard M, Drolet P. Intrathecal meperidine decreases shivering during cesarean delivery under spinal anesthesia. Anesth Analg. 2004; 98(1):230-234.

12. Khan ZH, Zanjani AP, Makarem J, Samadi S. Antishivering effects of two different doses of intrathecal meperidine in caesarean section: a prospective randomised blinded study. Eur J Anaesthesiol. 2011;28(3): 202-206.

13. Crossley AW, Mahajan RP. The intensity of postoperative shivering is unrelated to axillary temperature. Anaesthesia. 1994;49(3):205-207.

14. Hong J-Y, Lee IH. Comparison of the effects of intrathecal morphine and pethidine on shivering after caesarean delivery under combinedspinal epidural anaesthesia. Anaesthesia. 2005;60(12):1168-1172.

15. Kurz A, Sessler DI, Schroeder M, Kurz M. Thermoregulatory response threshold during spinal anesthesia. Anesth Analg. 1993;77(4): 721-726.

16. Pauca AL, Savage RT, Simpson S, Roy RC. Effect of pethidine, fentanyl and morphine on post-operative shivering in man. Acta Anaesthesiol Scand. 1984;28(2):138-143.
17. Rosow CE, Miller JM, Pelikan EW, Cochin J. Opiates and thermoregulation in mice. I. Agonists. J Pharmacol Exp Ther. 1980;213(2): 273-283.

18. Safavi M, Honarmand A, Negahban M, Attari M. Prophylactic effects of intrathecal meperidine and intravenous ondansetron on shivering in patients undergoing lower extremity orthopedic surgery under spinal anesthesia. J Res Pharm Pract. 2014;3(3):94-99.

19. Yu SC, Ngan Kee WD, Kwan AS. Intrathecal meperidine and shivering in obstetric anaesthesia. Anesth Analg. 2004;99(4):1272-1273.

20. Kurz A, Ikeda T, Sessler DI, et al. Meperidine decreases the shivering threshold twice as much as the vasoconstriction threshold. Anesthesiology. 1997;86(5):1046-1054.

21. Rastegarian A, Ghobadifar MA, Kargar H, Mosallanezhad Z. Intrathecal meperidine plus lidocaine for prevention of shivering during cesarean section. Korean J Pain. 2013;26(4):379-386.
Drug Design, Development and Therapy

\section{Publish your work in this journal}

Drug Design, Development and Therapy is an international, peerreviewed open-access journal that spans the spectrum of drug design and development through to clinical applications. Clinical outcomes, patient safety, and programs for the development and effective, safe, and sustained use of medicines are the features of the journal, which

\section{Dovepress}

has also been accepted for indexing on PubMed Central. The manuscript management system is completely online and includes a very quick and fair peer-review system, which is all easy to use. Visit http://www.dovepress.com/testimonials.php to read real quotes from published authors.

Submit your manuscript here: http://www.dovepress.com/drug-design-development-and-therapy-journal 